\title{
REVIEW
}

\section{Noninvasive ventilation and the upper airway: should we pay more attention?}

\author{
Eline Oppersma ${ }^{1,2}$, Jonne Doorduin², Erik HFM van der Heijden³ ${ }^{3}$, Johannes G van der Hoeven² \\ and Leo MA Heunks ${ }^{2^{*}}$
}

\begin{abstract}
In an effort to reduce the complications related to invasive ventilation, the use of noninvasive ventilation (NIV) has increased over the last years in patients with acute respiratory failure. However, failure rates for NIV remain high in specific patient categories. Several studies have identified factors that contribute to NIV failure, including low experience of the medical team and patient-ventilator asynchrony. An important difference between invasive ventilation and NIV is the role of the upper airway. During invasive ventilation the endotracheal tube bypasses the upper airway, but during NIV upper airway patency may play a role in the successful application of NIV. In response to positive pressure, upper airway patency may decrease and therefore impair minute ventilation. This paper aims to discuss the effect of positive pressure ventilation on upper airway patency and its possible clinical implications, and to stimulate research in this field.
\end{abstract}

\section{Introduction}

Noninvasive ventilation (NIV) is increasingly used in acute respiratory failure, for instance in patients with exacerbation of chronic obstructive pulmonary disease or acute heart failure [1-3]. An important goal of NIV is to prevent endotracheal intubation and thereby reduce the complications related to invasive ventilation $[1,4]$. However, failure rates of NIV range between 5 and 50\% [5,6] and most of these patients require endotracheal intubation [5-9]. Several factors have been identified that increase the success rate of NIV. These factors include careful selection of patients, properly timed intervention, a comfortable and well-fitting interface, coaching and

\footnotetext{
* Correspondence: Leo.Heunks@radboudumc.nl

${ }^{2}$ Department of Critical Care Medicine (707), Radboud university medical center, PO Box 9101, 6500 HB Nijmegen, the Netherlands

Full list of author information is available at the end of the article
}

encouragement of patients, careful monitoring, and a skilled and motivated team $[6,8,10]$. In particular, careful selection is of major importance in patients with chronic obstructive pulmonary disease. A low $\mathrm{pH}(<7.25)$ is a strong predictor of NIV failure [10,11], but an improvement in $\mathrm{pH} 1$ to 2 hours after the initiation of NIV accurately predicts NIV success [5,11-13].

Today, the pathophysiology of NIV failure is incompletely understood. How can ventilation be inadequate with NIV, but adequate with similar levels of support after endotracheal intubation? An important difference in the application of NIV versus invasive ventilation is, evidently, the involvement of the upper airway. During invasive ventilation the endotracheal tube bypasses the upper airway and the cuff of the endotracheal tube provides an air-tight seal in the trachea. In contrast, during NIV the upper airway might play a role in the efficiency of delivered ventilation. Indeed, ventilator settings during NIV affect the patency of the upper airway [14,15]. This effect implies that deviant behavior of the upper airway may play a role in the failure of NIV. The present concise review discusses the physiology and current understanding on the effects of NIV on upper airway patency. We will discuss the clinical relevance of the available studies and will list important points to stimulate research in this field.

\section{Noninvasive ventilation and upper airway physiology}

\section{Patient-ventilator asynchrony}

The aim of NIV is to decrease the work of breathing and/or improve oxygenation and ventilation. The most frequently used mode of NIV is pressure support ventilation (PSV). For the most effective unloading of the inspiratory muscles, the ventilator should cycle in synchrony with the patient's neural respiratory drive [16]. Although triggering and cycling of mechanical support during PSV depends on the patient's respiratory effort, asynchrony between the patient and ventilator occurs 
frequently [17]. Several types of asynchrony and dyssynchrony between the patient's neural drive and ventilator support have been identified and are shown in Figure $1[18,19]$. Suboptimal synchrony between the patient and the ventilator may be affected by respiratory mechanics, the breathing pattern, neural drive, ventilator settings, the type of interface and the amount of air leak [18,20-23]. The consequences of patient-ventilator asynchrony are poorly understood, but a high incidence of asynchrony is associated with discomfort and a prolonged duration of NIV [17].

The above-discussed types of asynchrony are related to the interaction between the activity of the inspiratory muscles and the ventilator's response. Indeed, this is sufficient for patients requiring invasive ventilation. However, during NIV it is also important that the ventilator acts in synchrony with the upper airway muscles. Glottic narrowing during inspiration increases upper airway resistance and may limit effective ventilation. We will discuss this type of asynchrony after briefly summarizing the knowledge of upper airway physiology relevant to the topic of this review.

\section{Upper airway}

The upper airway comprises the nose, oral cavity, pharynx and larynx. The upper airway is involved in chewing, swallowing, speech and smell, and its primary functions are to act as a conductor of air, to humidify and warm the inspired air and prevent foreign materials from entering the tracheobronchial tree [24]. The nose and oral cavity are mainly static in their conducting function, whereas the pharynx and larynx predominantly are muscular structures and thus may alter the patency of the upper airway $[15,25]$. A simplified representation of the muscles of the upper airway is shown in Figure 2 and a view of the intrinsic muscles of the larynx shown in Figure 3 [26,27].

Stella and England studied the effect of pressure and flow in isolated piglet upper airway [28]. They showed that the presence of negative pressure in the upper airway and flow during inspiration results in phasic respiratory activity of the posterior cricoarytenoid muscle above tonic levels, which results in glottic widening during inspiration and reduces resistance to airflow. This response effectively unloads the inspiratory muscles. Positive pressure and flow during expiration results in phasic activity of the thyroarytenoid muscle, resulting in glottic narrowing and therefore increased resistance to the expiratory flow. Accordingly, this study shows that, at least in an animal model, respiratory flow patterns affect the activity of the upper airway muscles.

Earlier, Sant'Ambrogio and colleagues showed that flow receptors actually respond to temperature changes from body to room temperature (thermoreceptors) [29]. Stella and England used these findings to analyze the laryngeal muscle response to continuous versus oscillating flow patterns and different body and room temperatures. They reported that a negative pressure and inspiratory flow results in increased posterior cricoarytenoid activity (opening of the glottis), independent of the stimulus modality. Furthermore, positive pressure and expiratory flow increased the thyroarytenoid activity for all stimuli, although constant room air applied to the upper airway results in more activity of the thyroarytenoid muscle than an oscillatory stimulus, implying that constant room air results in enhanced constriction of the glottis. Accordingly, both pressure and flow receptors play an important role in muscle activity of the upper airway during respiration $[28,30]$.

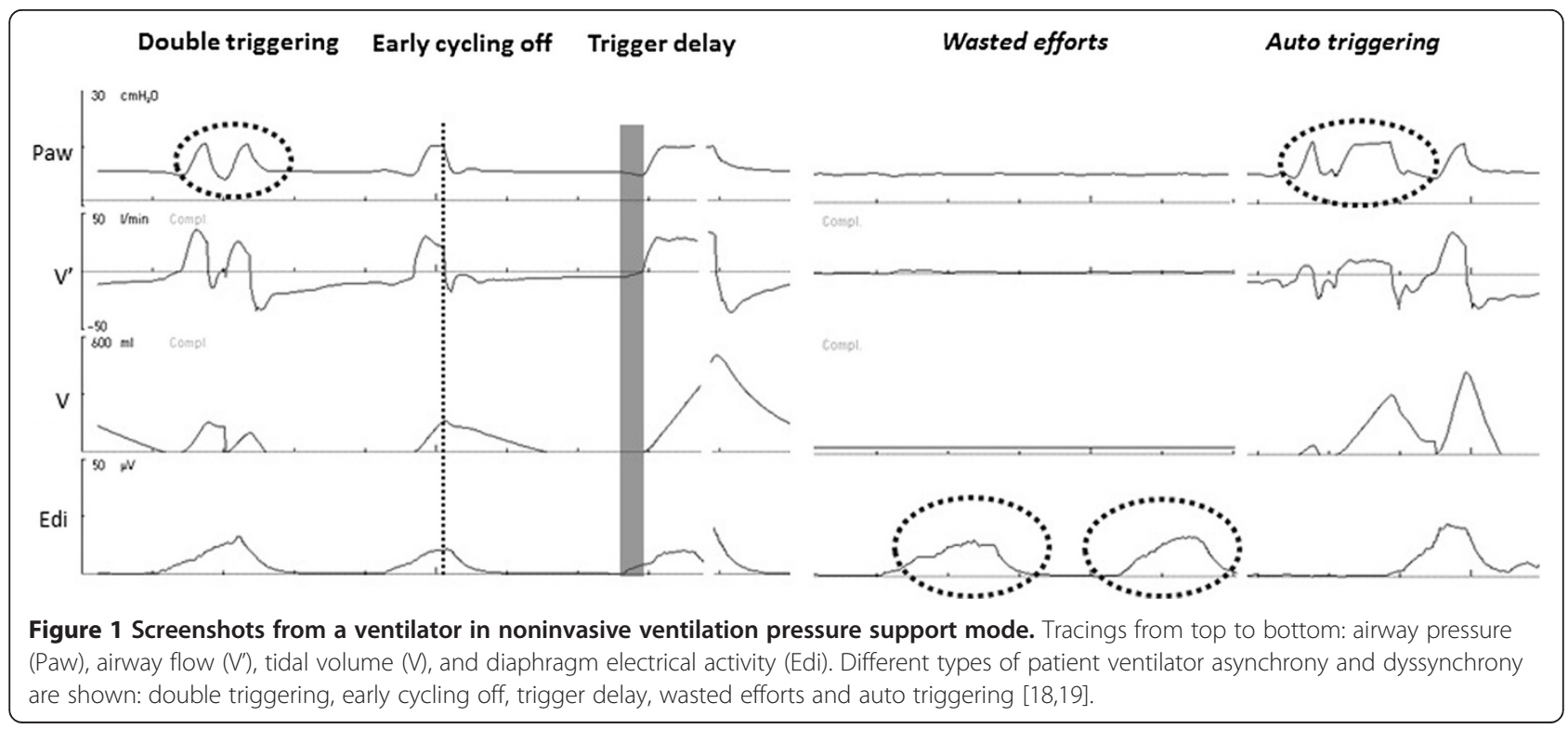




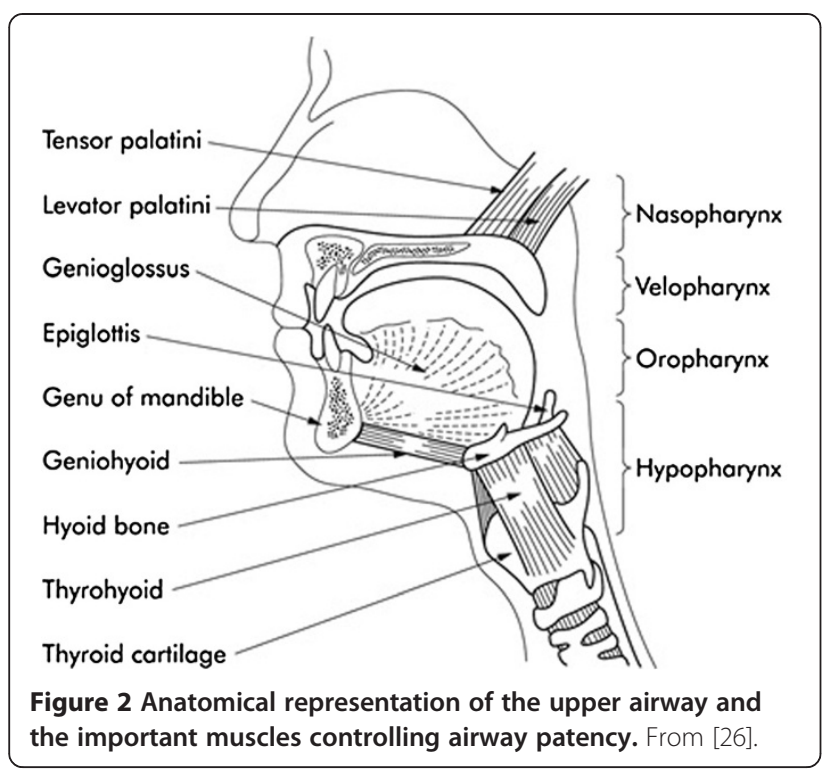

Receptors in the upper and lower airway modulate activity of the upper airway muscles. The most prominent receptors are the bronchopulmonary C-fiber receptors, rapidly adapting receptors (RARs) and slowly adapting pulmonary stretch receptors (PSRs) (Table 1).

Pulmonary C-fiber receptors are located between the alveolar epithelium and the pulmonary capillaries, whereas bronchial $\mathrm{C}$-fiber receptors have been identified in the conducting airway. The receptors' fiber endings extend into the space between epithelial cells or form a plexus immediately under the basement membrane. $\mathrm{C}$-fiber receptors are excited by large mechanical deformations, chemical stimuli (for example, capsaicin and carbon dioxide), lung edema by increased interstitial fluid volume, or increased temperature [31,32]. C-fiber receptor activation evokes inhibitory effects (apnea or bradypnea; hypotension and bradycardia). C-fiber receptor stimulation can result in closing of the upper airway by glottic narrowing to protect the respiratory system against inhalation of gaseous irritants, by activation of laryngeal muscles [33].

RARs are located in and under the epithelium throughout the respiratory tract from the nose to the bronchi. The receptors respond in reaction to mechanical (extremely sensitive) and chemical stimuli, and produce mainly excitatory effects such as tachypnea $[33,34]$. The RARs in the larynx are usually called irritant receptors because of their activation by inhaled irritants such as ammonia or cigarette smoke, and they probably cause cough and expiration reflexes. When the laryngeal mucosa is stimulated, RAR reflexes elicit laryngoconstriction and bronchoconstriction, which may be part of the glottal closure seen during cough. However, the exact modulation of laryngeal upper airway muscle activities by RARs is incompletely understood [31,33,34].

PSRs do not affect patency of the upper airway but modulate the respiratory cycle: they terminate inspiration and extend expiration [35]. PSRs are activated by stretching the airway wall and fire throughout the respiratory cycle (tonic activity) or in response to lung inflation (phasic activity). The discharge rate is progressively increased as a function of lung volume. PSRs are also widely known as the receptors responsible for the Hering-Breuer reflex, one of the first negative feedback loops in physiology. Hering and Breuer found that lung inflation decreases the tidal volume and increases the respiratory rate, thereby protecting the lungs from hyperinflation, while maintaining constant alveolar ventilation: an inspiratory off-switch $[33,36]$.

To summarize, respiration and in particular patency of the upper airway depends on a complex, but incompletely understood, interplay between several inhibitory

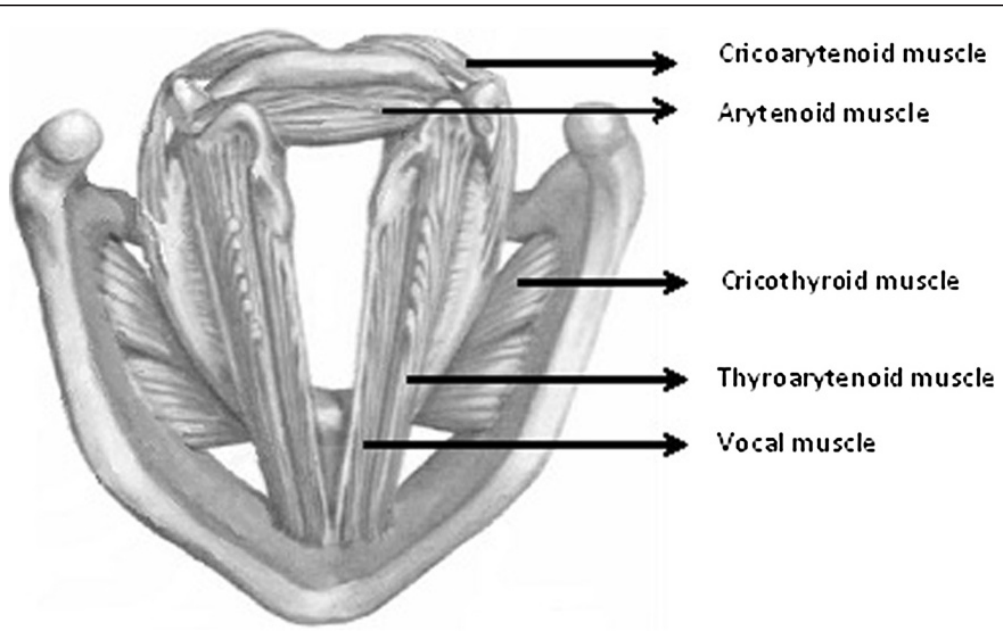

Figure 3 Intrinsic muscles of the larynx. From [27]. 
Table 1 Relevant respiratory receptors and their location and effect

\begin{tabular}{|c|c|c|c|c|}
\hline Receptors & & Location & Stimulus & Effect \\
\hline C-fiber & $\begin{array}{l}\text { Pulmonary } \\
\text { Bronchial }\end{array}$ & $\begin{array}{l}\text { Between alveolar epithelium } \\
\text { and pulmonary capillary } \\
\text { In the walls of conducting airway }\end{array}$ & $\begin{array}{l}\text { Large mechanical } \\
\text { deformations, chemical } \\
\text { stimuli and temperature increases }\end{array}$ & $\begin{array}{l}\text { Inhibitory effects as apnea, } \\
\text { hypotension and bradycardia }\end{array}$ \\
\hline Rapidly adapting & & $\begin{array}{l}\text { In epithelium close to } \\
\text { bronchial venules }\end{array}$ & $\begin{array}{l}\text { Very sensitive to mechanical } \\
\text { stimuli and slow response to } \\
\text { chemical stimuli }\end{array}$ & $\begin{array}{l}\text { Irritant receptors cause cough } \\
\text { and expiration reflexes }\end{array}$ \\
\hline Pulmonary stretch & & $\begin{array}{l}\text { In close association with airway } \\
\text { smooth muscle }\end{array}$ & $\begin{array}{l}\text { Mechanical changes, stretch of } \\
\text { airway wall }\end{array}$ & $\begin{array}{l}\text { Terminate inspiration and extend } \\
\text { expiration (Hering-Breuer reflex). }\end{array}$ \\
\hline
\end{tabular}

and excitatory pathways. Physical conditions such as pressure, flow and temperature affect upper airway patency. NIV may affect these physical characteristics and therefore affect patency of the upper airway.

\section{Interaction between the upper airway and noninvasive ventilation}

Moreau-Bussière and colleagues studied the effect of NIV on activity of the glottal constrictor (thyroarytenoid) and dilator (cricothyroid) muscles in awake lambs. Figure 4 shows thyroarytenoid, cricothyroid and diaphragm muscle activity during spontaneous breathing or NIV with PSV [37]. During spontaneous breathing, both the thyroarytenoid and cricothyroid muscles are active thyroarytenoid muscle activity occurring primarily at the end of inspiration. However, with application of pressure support during NIV, inspiratory cricothyroid activity disappears whereas activity of the thyroarytenoid muscle increases. This results in glottal narrowing and restricted ventilation, as reflected by respiratory inductance phlethysmography [37].

A subsequent study demonstrated that increased glottal constrictor muscle activity during NIV depends mainly on activation of bronchopulmonary receptors. After bilateral vagotomy, the increase in inspiratory activity of the thyroarytenoid muscle previously observed with increasing support during NIV was absent [14].

There are limited data that demonstrate a similar response to NIV in humans. Rodenstein and colleagues exposed healthy subjects to increasing levels of support with NIV while their glottis was continuously monitored through a fiberoptic bronchoscope. The higher the level of support, the narrower the glottic aperture and the higher the airway resistance. This effect led to

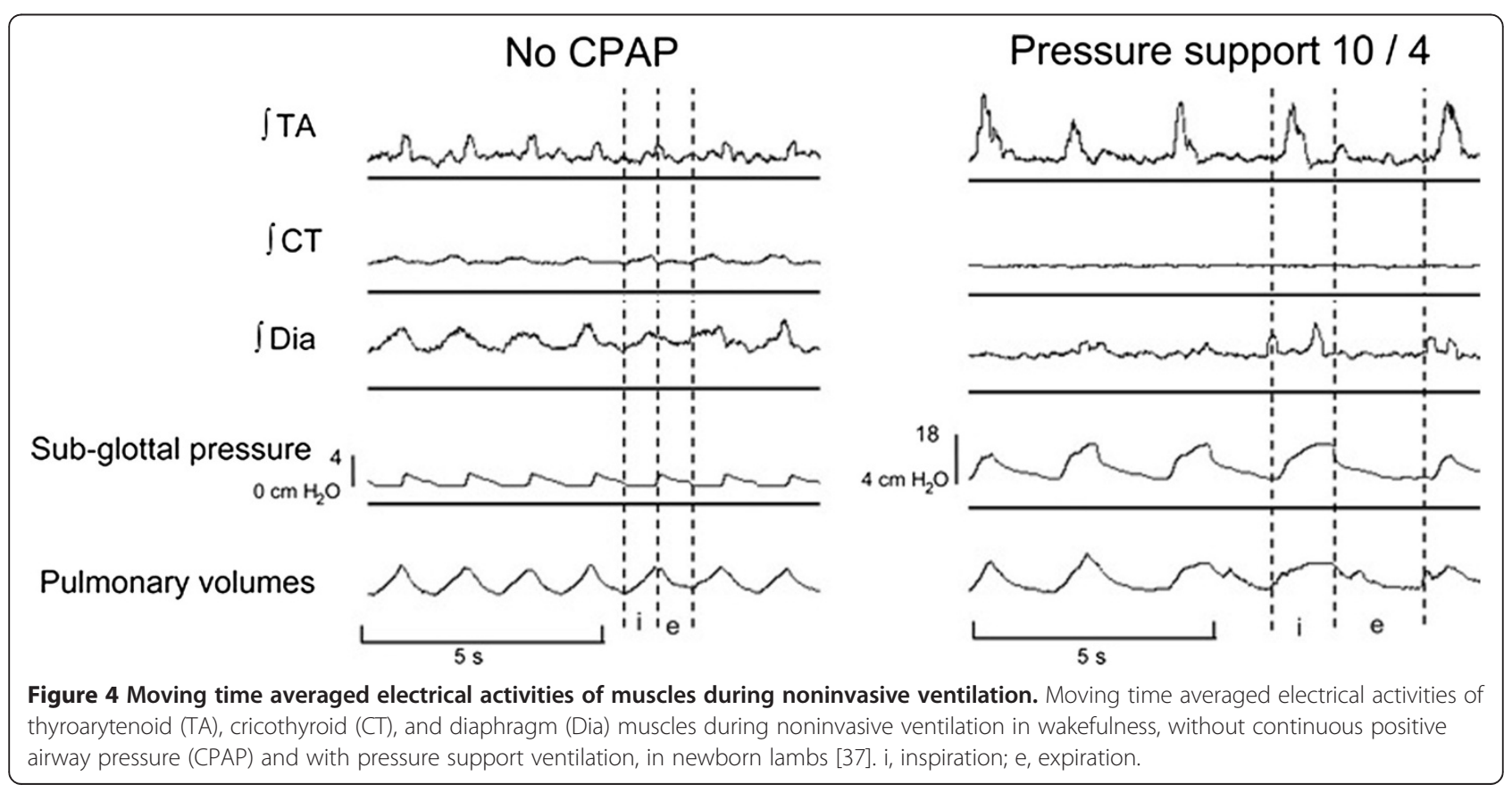


a progressive decrease in the percentage of tidal volume effectively reaching the lungs, apparently at least partly due to the behavior of the glottis $[15,38,39]$.

In summary, studies in animals and humans indicate that positive pressure ventilation reduces patency of the upper airway during neural inspiration.

Neurally adjusted ventilator assist (NAVA) is a relatively new mode of noninvasive ventilatory support. The key features of NAVA are that the ventilator is cycled by diaphragm electrical activity, thereby improving patientventilator synchrony $[40,41]$, and that the level of support is proportional to the electrical activity of the diaphragm [42]. The electrical activity of the diaphragm is measured by an array of bipolar electrodes mounted on a nasogastric feeding tube.

In contrast to PSV, glottal constrictor muscle activity does not increase with NAVA during inspiration in lambs [43]. Apparently, NAVA induces less glottal closure and more synchronous ventilation and may thus be advantageous compared with PSV during NIV. A possible underlying mechanism for the absence of glottal constrictor activity during inspiration with NAVA is that the pressure rise mimics the normal progressive recruitment of the diaphragmatic motor units, whereas during PSV insufflation from the ventilator is performed with a constant level of pressure (decelerating flow pattern), often with a short inspiratory rise time to further decrease the patient's inspiratory work. The consequent rapid nonphysiological rise in airway pressure at the onset of inspiration with PSV could be responsible for activating, in a reflex manner, the inspiratory activity of the glottal constrictor muscles and thus limits the efficiency of NIV [43]. This hypothesis should be the subject of further clinical research.

\section{Monitoring muscles of the upper airway}

The importance of monitoring inspiratory muscle activity during mechanical ventilation has been stressed in the literature [44]. In contrast, little is known about the role of monitoring upper airway activity during NIV probably related to the complexity of monitoring the upper airway function in these patients.

Activation of intrinsic laryngeal muscles affects glottis opening and thus affects resistance to flow into and out of the lungs [28]. Monitoring the recruitment of upper airway dilator muscles during inspiration could be clinically relevant because the phasic activity of upper airway dilator muscles increases with respiratory constraints, as in patient-ventilator asynchrony $[45,46]$. Cheng and colleagues studied the upper airway in healthy subjects, using magnetic resonance imaging with tagging [47]. This study showed not only that the genioglossus muscle but also nonmuscular soft tissues surrounding the upper airway move before the onset of inspiratory flow [47].
Movement of certain reference points on the genioglossus muscle was greater during normal inspiration than during loaded inspiration, suggesting that the increase in activity of the muscle during loaded inspiration does not result in dilation but in stiffening of the upper airway [47]. Moreover, this study demonstrated that movement of nonmuscular soft tissue affects upper airway patency.

A complex interaction exists between movement of nonmuscular soft tissue and genioglossus muscle activity. Although laryngeal muscle (for example, genioglossus or cricothyroid muscle) electromyography is feasible during NIV $[37,45]$, one should note that electromyography does not provide information about nonmuscular soft tissue movement. Additional techniques should therefore be used to evaluate upper airway patency. Magnetic resonance imaging probably provides the most reliable information but it is expensive and cumbersome, particularly in patients on NIV. Recently, a study showed that the upper airway could be visualized with ultrasound, although the value of assessing upper airway patency with this technique has not been studied [48]. In addition, endoscopy has been used to assess upper airway patency, but ideally should be used at different levels in the upper airway.

\section{Clinical relevance and future research}

Increasing the success rate of NIV is of major clinical importance. In contrast to invasive ventilation, the upper airway plays an important role as a conductor of air during NIV. Current literature suggests that during NIV it is important that the ventilator acts in synchrony with the upper airway muscles to allow adequate ventilation. In lambs and piglets, the patency of the upper airway is influenced by ventilator-induced changes in pressure and flow [14,30,37,43]. However, we do not know whether this phenomenon can be extrapolated to humans. The involved reflexes are similar in humans to those in newborn lambs, but are thought to be less pronounced.

Today, there are limited data on the effects of NIV on upper airway physiology in patients with acute respiratory failure. It is reasonable to assume that when the ventilator cycles in synchrony with the upper airway, this will improve efficiency of ventilation. As discussed, upper airway patency is linked to neural respiratory drive. Therefore, improved synchrony between the ventilator and respiratory drive may improve ventilation partly by limiting wasted ventilation at the level of the upper airway. Currently, it would be preliminary to provide recommendations on how the level of assist, level of positive end-expiratory pressure and flow pattern should be adapted to enhance patency of the upper airway in patients with acute respiratory failure. 
Future research should therefore aim at studying the effect of different ventilator modes and settings on the patency of the upper airway in patients. For example, NAVA ventilation in lambs has been shown to decrease glottal constrictor muscle activity compared with PSV during NIV. Settings of the ventilator such as the rise time, trigger sensitivity, and the level of pressure support and positive end-expiratory pressure should also be the subject of further research. These settings could influence the behavior of the upper airway and potentially limit adequate lung ventilation. Currently, a study is investigating the effect of ventilator settings during NIV on upper airway patency in patients with an exacerbation of chronic obstructive pulmonary disease (Clinicaltrials.gov ID: NCT01791335). Our recommendations for further research focus on inspiration, but expiration could also be influenced by upper airway patency.

\section{Conclusions}

In conclusion, we have shown that regulation of the upper airway is complex and influenced by NIV. The latter findings are mostly based on animal data. Understanding of the laryngeal reactions during different modes and settings of NIV in patients will be crucial to determine whether a diminished upper airway patency contributes to NIV failure.

\section{Abbreviations \\ NAVA: Neurally adjusted ventilator assist; NIV: Noninvasive ventilation; PSR: Pulmonary stretch receptor; PSV: Pressure support ventilation; RAR: Rapidly adapting receptor.}

\section{Competing interests}

The authors declare that they have no competing interests.

\section{Author details}

${ }^{1}$ MIRA - Institute for Biomedical Technology \& Technical Medicine, University of Twente, PO Box 217, 7500 AE Enschede, the Netherlands. ${ }^{2}$ Department of Critical Care Medicine (707), Radboud university medical center, PO Box 9101, 6500 HB Nijmegen, the Netherlands. ${ }^{3}$ Department of Pulmonology (454), Radboud university medical center, PO Box 9101, 6500 HB Nijmegen, the Netherlands.

\section{Published: 05 Dec 2013}

\section{References}

1. Brochard L, Mancebo J, Elliott MW: Noninvasive ventilation for acute respiratory failure. Eur Respir J 2002, 19:712-721.

2. Dickstein $K$, Cohen-Solal A, Filippatos G, McMurray JJ, Ponikowski $P$, Poole-Wilson PA, Stromberg A, van Veldhuisen DJ, Atar D, Hoes AW, Keren A, Mebazaa A, Nieminen M, Priori SG, Swedberg K, ESC Committee for Practice Guidelines: ESC guidelines for the diagnosis and treatment of acute and chronic heart failure 2008: the Task Force for the diagnosis and treatment of acute and chronic heart failure 2008 of the European Society of Cardiology. Developed in collaboration with the Heart Failure Association of the ESC (HFA) and endorsed by the European Society of Intensive Care Medicine (ESICM). Eur J Heart Fail 2008, 10:933-989.

3. Chandra D, Stamm JA, Taylor B, Ramos RM, Satterwhite L, Krishnan JA Mannino D, Sciurba FC, Holguin F: Outcomes of noninvasive ventilation for acute exacerbations of chronic obstructive pulmonary disease in the United States, 1998-2008. Am J Respir Crit Care Med 2012, 185:152-159.
4. Boldrini R, Fasano L, Nava S: Noninvasive mechanical ventilation. Curr Opin Crit Care 2012, 18:48-53.

5. Moretti M, Cilione C, Tampieri A, Fracchia C, Marchioni A, Nava S: Incidence and causes of non-invasive mechanical ventilation failure after initial success. Thorax 2000, 55:819-825

6. Antonelli M, Conti G, Moro ML, Esquinas A, Gonzalez-Diaz G, Confalonieri M, Pelaia P, Principi T, Gregoretti C, Beltrame F, Pennisi MA, Arcangeli A, Proietti R, Passariello M, Meduri GU: Predictors of failure of noninvasive positive pressure ventilation in patients with acute hypoxemic respiratory failure: a multi-center study. Intensive Care Med 2001, 27:1718-1728.

7. Lightowler JV, Wedzicha JA, Elliott MW, Ram FS: Non-invasive positive pressure ventilation to treat respiratory failure resulting from exacerbations of chronic obstructive pulmonary disease: Cochrane systematic review and meta-analysis. BMJ 2003, 326:185.

8. Carlucci A, Richard JC, Wysocki M, Lepage E, Brochard L: Noninvasive versus conventional mechanical ventilation. An epidemiologic survey. Am J Respir Crit Care Med 2001, 163:874-880

9. Keenan SP, Mehta S: Noninvasive ventilation for patients presenting with acute respiratory failure: the randomized controlled trials. Respir Care 2009, 54:116-126.

10. Confalonieri M, Garuti G, Cattaruzza MS, Osborn JF, Antonelli M, Conti G Kodric M, Resta O, Marchese S, Gregoretti C, Rossi A, Italian Noninvasive Positive Pressure Ventilation (NPPV) Study Group: A chart of failure risk for noninvasive ventilation in patients with COPD exacerbation. Eur Respir J 2005, 25:348-355.

11. Mehta S, Hill NS: Noninvasive ventilation. Am J Respir Crit Care Med 2001, 163:540-577.

12. Meduri GU, Turner RE, Abou-Shala N, Wunderink R, Tolley E: Noninvasive positive pressure ventilation via face mask. First-line intervention in patients with acute hypercapnic and hypoxemic respiratory failure. Chest 1996, 109:179-193.

13. Ambrosino N, Foglio K, Rubini F, Clini E, Nava S, Vitacca M: Non-invasive mechanical ventilation in acute respiratory failure due to chronic obstructive pulmonary disease: correlates for success. Thorax 1995, 50:755-757.

14. Roy B, Samson N, Moreau-Bussière F, Ouimet A, Dorion D, Mayer S, Praud J-P: Mechanisms of active laryngeal closure during noninvasive intermittent positive pressure ventilation in nonsedated lambs. J Appl Physiol 2008, 105:1406-1412.

15. Parreira VF, Jounieaux V, Aubert G, Dury M, Delguste PE, Rodenstein DO: Nasal two-level positive-pressure ventilation in normal subjects. Effects of the glottis and ventilation. Am J Respir Crit Care Med 1996, 153:1616-1623.

16. Tobin MJ, Jubran A, Laghi F: Patient-ventilator interaction. Am J Respir Crit Care Med 2001, 163:1059-1063.

17. Vignaux L, Vargas F, Roeseler J, Tassaux D, Thille A, Kossowsky M, Brochard $L$, Jolliet P: Patient-ventilator asynchrony during non-invasive ventilation for acute respiratory failure: a multicenter study. Intensive Care Med 2009, 35:840-846.

18. Thille AW, Rodriguez P, Cabello B, Lellouche F, Brochard L: Patient-ventilator asynchrony during assisted mechanical ventilation. Intensive Care Med 2006, 32:1515-1522.

19. Sassoon C: Triggering of the ventilator in patient-ventilator interactions. Respir Care 2011, 56:39-51.

20. Colombo D, Cammarota G, Alemani M, Carenzo L, Barra FL, Vaschetto R, Slutsky AS, Della Corte F, Navalesi P: Efficacy of ventilator waveforms observation in detecting patient-ventilator asynchrony. Crit Care Med 2011, 39:2452-2457.

21. Leung $P$, Jubran A, Tobin MJ: Comparison of assisted ventilator modes on triggering, patient effort, and dyspnea. Am J Respir Crit Care Med 1997, 155:1940-1948.

22. Navalesi P, Costa R: New modes of mechanical ventilation: proportional assist ventilation, neurally adjusted ventilatory assist, and fractal ventilation. Curr Opin Crit Care 2003, 9:51-58.

23. Murata S, Yokoyama K, Sakamoto Y, Yamashita K, Oto J, Imanaka H, Nishimura M: Effects of inspiratory rise time on triggering work load during pressure-support ventilation: a lung model study. Respir Care 2010, 55:878-884.

24. Des Jardins TR: Cardiopulmonary Anatomy \& Physiology: Essentials for Respiratory Care. 5th edition. Clifton Park, NY: Thomson Delmar Learning London: Thomson Learning (distributor); 2008. 
25. Mittal RK: Motor Function of the Pharynx, Esophagus, and its Sphincters. Morgan \& Claypool Life Sciences: San Rafael, CA; 2011.

26. Fogel RB, Malhotra A, White DP: Sleep. 2: pathophysiology of obstructive sleep apnoea/hypopnoea syndrome. Thorax 2004, 59:159-163.

27. Netter medical illustration used with permission of Elsevier. All rights reserved. [http://www.netterimages.com/image/20362.htm]

28. Stella MH, England SJ: Modulation of laryngeal and respiratory pump muscle activities with upper airway pressure and flow. J Appl Physiol 2001, 91:897-904.

29. Sant'Ambrogio G, Tsubone H, Sant'Ambrogio FB: Sensory information from the upper airway: role in the control of breathing. Respir Physiol 1995, 102:1-16.

30. Stella MH, England SJ: Laryngeal muscle response to phasic and tonic upper airway pressure and flow. J Appl Physiol 2001, 91:905-911.

31. Kubin L, Alheid GF, Zuperku EJ, McCrimmon DR: Central pathways of pulmonary and lower airway vagal afferents. J Appl Physiol 2006 101:618-627.

32. Lee LY, Pisarri TE: Afferent properties and reflex functions of bronchopulmonary C-fibers. Respir Physiol 2001, 125:47-65.

33. Bailey EF, Fregosi RF: Modulation of upper airway muscle activities by bronchopulmonary afferents. J App/ Physio/ 2006, 101:609-617.

34. Sant'Ambrogio G, Widdicombe J: Reflexes from airway rapidly adapting receptors. Respir Physiol 2001, 125:33-45.

35. Davies A, Pirie L, Eyre-Todd RA: Adaptation of pulmonary receptors in the spontaneously breathing anaesthetized rat. Eur Respir J 1996, 9:1637-1642.

36. Boron WF, Boulpaep EL: Medical Physiology: A Cellular and Molecular Approach. Updated 2nd edition. Philadelphia, PA: Saunders; 2012.

37. Moreau-Bussière F, Samson N, St-Hilaire M, Reix P, Lafond JR, Nsegbe É, Praud J-P: Laryngeal response to nasal ventilation in nonsedated newborn lambs. J Appl Physiol 2007, 102:2149-2157.

38. Jounieaux V, Aubert G, Dury M, Delguste P, Rodenstein DO: Effects of nasal positive-pressure hyperventilation on the glottis in normal sleeping subjects. J Appl Physiol 1995, 79:186-193.

39. Jounieaux V, Aubert G, Dury M, Delguste P, Rodenstein DO: Effects of nasal positive-pressure hyperventilation on the glottis in normal awake subjects. J Appl Physiol 1995, 79:176-185.

40. Piquilloud L, Tassaux D, Bialais E, Lambermont B, Sottiaux T, Roeseler J, Laterre PF, Jolliet P, Revelly JP: Neurally adjusted ventilatory assist (NAVA) improves patient-ventilator interaction during non-invasive ventilation delivered by face mask. Intensive Care Med 2012, 38:1624-1631.

41. Bertrand PM, Futier E, Coisel Y, Matecki S, Jaber S, Constantin JM: Neurally adjusted ventilator assist versus pressure support ventilation for noninvasive ventilation during acute respiratory failure: a cross-over physiological study. Chest 2013, 143:30-36.

42. Sinderby C, Navalesi P, Beck J, Skrobik Y, Comtois N, Friberg S, Gottfried SB, Lindstrom $\mathrm{L}$ : Neural control of mechanical ventilation in respiratory failure. Nat Med 1999, 5:1433-1436.

43. Hadj-Ahmed MA, Samson N, Bussieres M, Beck J, Praud JP: Absence of inspiratory laryngeal constrictor muscle activity during nasal neurally adjusted ventilatory assist in newborn lambs. J App/ Physio/ 2012, 113:63-70.

44. Doorduin J, van Hees HW, van der Hoeven JG, Heunks LM: Monitoring of the respiratory muscles in the critically ill. Am J Respir Crit Care Med 2013, 187:20-27.

45. Hug F, Raux M, Morelot-Panzini C, Similowski T: Surface EMG to assess and quantify upper airway dilators activity during non-invasive ventilation. Respir Physiol Neurobiol 2011, 178:341-345.

46. Schmidt M, Chiti L, Hug F, Demoule A, Similowski T: Surface electromyogram of inspiratory muscles: a possible routine monitoring tool in the intensive care unit. Br J Anaesth 2011, 106:913-914
47. Cheng S, Butler JE, Gandevia SC, Bilston LE: Movement of the human upper airway during inspiration with and without inspiratory resistive loading. J App/ Physiol 2011, 110:69-75.

48. Cheng SP, Lee JJ, LiU TP, Lee KS, Liu CL: Preoperative ultrasonography assessment of vocal cord movement during thyroid and parathyroid surgery. World J Surg 2012, 36:2509-2515.

$10.1186 / \mathrm{cc} 13141$

Cite this article as: Oppersma et al:: Noninvasive ventilation and the upper airway: should we pay more attention? Critical Care 2013, 17:245 